\title{
The effect of dietary restriction on muscle fibre length in mice
}

\author{
BY A.C. B. HOOPER \\ Department of Anatomy, University College, Dublin, Irish Republic
}

(Received 11 August 1983 - Accepted 7 December 1983)

1. The dietary intake of male mice from a line selected for high body-weight was restricted to $60 \%$ by weight of the ad lib. intake of the control litter-mates between days 21 and 42 post partum.

2. One group was killed and compared with controls at $42 \mathrm{~d}$ of age. A further group then resumed ad lib. feeding. Mice which had regained the control body-weight by $61 \mathrm{~d}$ of age were killed and also compared with controls.

3. Muscle weight, fibre length, sarcomere length, sarcomere number per fibre, actin length and myosin length were measured in the biceps brachii and tibialis anterior muscles.

4. Muscle weight, fibre length and the number of sarcomeres per fibre were significantly reduced in both muscles following dietary restriction, but regained their control values following a resumption of normal feeding. The other indices remained unchanged throughout the study.

5. The pattern of fibre length changes, due entirely to alterations in sarcomere number, is similar to that reported previously during growth, senescence and immobilization and following selection for high and low body-weights.

Muscle wasting is a well-recognized feature of nutritional deprivation. A decrease in muscle mass can occur as a result of changes in one or more of the indices of muscle growth, namely the number of fibres and their transverse and longitudinal dimensions. There are conflicting reports about the behaviour of fibre number during dietary restriction. A permanent non-reversible decrease in fibre number was reported in rats undernourished during gestation and suckling by restriction of the maternal food supply (Birzgalis et al. 1980). Dietary restriction resulted in muscle fibre loss in weanling rats (Layman et al. 1981) while total starvation produced a similar effect in some but not all the muscles of post-weaning animals from several species (Hegarty \& Kim, 1981). However, Rowe (1968) and Birzgalis et al. (1980) found unchanged numbers of fibres in the muscles of animals whose diet was restricted subsequent to weaning. A decrease in fibre diameter during dietary restriction, which can be reversed by restoration of a normal plane of nutrition, is well documented (see, for example, Joubert, 1956; Goldspink, 1965; Rowe, 1968).

Muscle fibre length, on the other hand, has not received the same attention. The length of the calf muscles is reportedly less in undernourished rats than in their normally-fed litter-mates (Williams \& Hughes, 1978). However, muscle length was not measured directly in the latter study but was deduced from radiographic measurements of the tibia, a technique which did not permit the study of changes in the functional units, the fibres. The present investigation was undertaken to determine the effect of post-weaning dietary restriction on the length of muscle fibres and the components of fibre length, namely sarcomere length, sarcomere number and the length of the actin and myosin filaments.

\section{EXPER I MENT AL}

\section{Animals}

Male mice, from a line selected for high body-weight, which grow rapidly in the immediate post-weaning phase were studied. This line was originally derived from the $Q$ strain founded in the Institute of Animal Genetics, Edinburgh (Falconer, 1973), and had undergone fifteen generations of selection. The line was subsequently maintained with twenty-five generations of random mating. Mice were weaned at $20 \mathrm{~d}$ post partum and housed individually in plastic cages in a temperature-, light- and humidity-controlled laboratory. Throughout the study, 
all animals received water ad lib. and were given standard pellets of a commercial diet manufactured by Odlum Mills Ltd, Dublin, which complied with accepted international dietary requirements (Laboratory Animal Science Association, 1969). Thirty mice designated as controls received this diet ad lib. Thirty litter-mates of these animals received $60 \%$ by weight of the ad lib. intake in a single daily feeding for $21 \mathrm{~d}$. On the next day (day 42 ) fifteen of these mice were killed along with fifteen controls. The remaining mice whose diet had been restricted were permitted to resume ad lib. feeding. By day 61 , thirteen of these mice had achieved the mean body-weight of their control litter-mates and were killed along with them. All mice were killed by diethyl ether anaesthesia immediately after the recording of their body-weight. Losses during subsequent processing restricted the investigation to ten mice per group.

\section{Preparative procedures}

Immediately after death, the left biceps brachii and tibialis anterior muscles were excised. The carcasses were then pinned out with the limbs in full extension and the forelimbs supinated. They remained in this position at room temperature $\left(20^{\circ}\right)$ for $6 \mathrm{~h}$, a period sufficient to allow the onset of rigor mortis to occur (Heffron \& Hegarty, 1974).

A block of tissue measuring approximately $5 \times 1 \mathrm{~mm}$ in size, with its long axis parallel to the long axis of the muscle, was removed from the mid-region of the excised muscles and fixed in gluteraldehyde. The mean actin length and mean myosin length of each muscle was then determined, using the preparative, examination and measurement procedures described by Hooper \& Hurley (1983).

After the onset of rigor mortis the muscles from the right side were excised in continuity with their tendons. After removal of any adherent fat or connective tissue, the muscles were weighed on a torsion balance and divided longitudinally into two portions. Fibres were separated from one portion of each muscle using the technique described by Hegarty \& Naude (1970). The image of fifteen randomly-chosen fibres was projected on to white card at a magnification of $\times 750$. The number of $A$ bands along a $100 \mu \mathrm{m}$ length of fibre was counted, and the mean sarcomere length of the muscle calculated. A second portion of each muscle was placed in $\mathbf{4} \mathrm{M}$-nitric acid for $24 \mathrm{~h}$ to hydrolyse the connective tissue, transferred to a flat-bottomed tube containing $1 \mathrm{ml}$ Ringer-Locke solution and clamped in the arms of a wrist-action flask shaker. Agitation for $1 \mathrm{~min}$ at approximately 1000 oscillations/min separated intact fibres to form a suspension. Mean fibre length and mean sarcomere length were then calculated for fifteen randomly-chosen fibres per muscle, using the method described by Hooper (1976a).

\section{Statistical methods}

Values were analysed in two ways. Means for mean actin length per muscle and mean myosin length per muscle were calculated along with their standard errors and compared using Student's $t$ test. Then least squares analysis of the main part of the values was performed, using a model with line as a fixed effect and error as a random effect. Mean values for body-weight, muscle weight, fibre length, mean sarcomere length and sarcomere length per fibre were then compared using Student's $t$ test.

\section{RESULTS}

The dietary restriction imposed produced a reduction in body-weight and in the weight of the two muscles studied (Table 1). However, the return to unrestricted feeding abolished these differences. The lengths of the fibres of the two muscles were also diminished as a result of the restricted feeding (Table 2) but regained their control values after a return to a normal 
Table 1. The effects of dietary restriction on body-weight and muscle weight of male mice

\begin{tabular}{lccc}
\hline & & \multicolumn{2}{c}{ Muscle wt (mg) } \\
\cline { 3 - 4 } Treatment & $\begin{array}{c}\text { Body-wt } \\
\text { (g) }\end{array}$ & $\begin{array}{c}\text { Biceps } \\
\text { brachii }\end{array}$ & $\begin{array}{c}\text { Tibialis } \\
\text { anterior }\end{array}$ \\
\hline Restricted diet & $17 \cdot 4^{* * *}$ & $11 \cdot 2^{* *}$ & $25 \cdot 4^{* * *}$ \\
Control (42 d) & $33 \cdot 2$ & $17 \cdot 4$ & $42 \cdot 4$ \\
Restricted diet, refed & $34 \cdot 8$ & $17 \cdot 8$ & $36 \cdot 8$ \\
Control (60 d) & $32 \cdot 7$ & $16 \cdot 8$ & $36 \cdot 3$ \\
SE & $1 \cdot 2$ & $1 \cdot 1$ & $1 \cdot 4$ \\
\hline
\end{tabular}

Mean values were significantly lower than the corresponding control value: ${ }^{* *} P<0.005,{ }^{* * *} P<0.001$.

Table 2. The effect of dietary restriction on fibre length and its components in male mice

\begin{tabular}{|c|c|c|c|c|c|c|}
\hline \multirow[b]{2}{*}{ Treatment } & \multicolumn{2}{|c|}{ Fibre length (mm) } & \multicolumn{2}{|c|}{$\begin{array}{l}\text { Mean sarcomere } \\
\text { length }(\mu \mathrm{m})\end{array}$} & \multicolumn{2}{|c|}{$\begin{array}{c}\text { Sarcomere number } \\
\text { per fibre }\end{array}$} \\
\hline & $\begin{array}{l}\text { Biceps } \\
\text { brachii }\end{array}$ & $\begin{array}{l}\text { Tibialis } \\
\text { anterior }\end{array}$ & $\begin{array}{l}\text { Biceps } \\
\text { brachii }\end{array}$ & $\begin{array}{c}\text { Tibialis } \\
\text { anterior }\end{array}$ & $\begin{array}{l}\text { Biceps } \\
\text { brachii }\end{array}$ & $\begin{array}{l}\text { Tibialis } \\
\text { anterior }\end{array}$ \\
\hline Restricted diet & $3 \cdot 4^{* *}$ & $5 \cdot 9^{* * *}$ & 2.63 & $2 \cdot 48$ & $1285^{* *}$ & $2314^{* *}$ \\
\hline Control (42 d) & $5 \cdot 0$ & $7 \cdot 3$ & $2 \cdot 51$ & $2 \cdot 48$ & 1971 & 2916 \\
\hline Restricted diet, refed & $5 \cdot 9$ & $7 \cdot 9$ & $2 \cdot 54$ & $2 \cdot 50$ & 2325 & 3129 \\
\hline Control $(60 \mathrm{~d})$ & $6 \cdot 0$ & $7 \cdot 6$ & $2 \cdot 52$ & $2 \cdot 45$ & 2377 & 3056 \\
\hline $\mathbf{S E}$ & $0 \cdot 2$ & 0.2 & 0.06 & 0.05 & 86 & 84 \\
\hline
\end{tabular}

Mean values were significantly lower than the control values: ${ }^{* *} P<0.005,{ }^{* * *} P<0.001$.

Table 3. The effect of dietary restriction on myofilament length in male mice

\begin{tabular}{lccccc}
\hline \hline & \multicolumn{2}{c}{ Actin $(\mu \mathrm{m})$} & & \multicolumn{2}{c}{ Myosin $(\mu \mathrm{m})$} \\
\cline { 2 - 3 } \cline { 5 - 6 } Treatment & $\begin{array}{c}\text { Biceps } \\
\text { brachii }\end{array}$ & $\begin{array}{c}\text { Tibialis } \\
\text { anterior }\end{array}$ & & $\begin{array}{c}\text { Biceps } \\
\text { brachii }\end{array}$ & $\begin{array}{c}\text { Tibialis } \\
\text { anterior }\end{array}$ \\
\hline Restricted diet & 1.91 & 1.83 & 1.50 & 1.38 \\
Control & 2.05 & 1.82 & & 1.53 & 1.40 \\
SE & 0.06 & 0.05 & & 0.05 & 0.03 \\
\hline
\end{tabular}

* There were no significant differences between treatments.

diet. The results in Table 2 also show that the reductions in fibre length were due to reduced numbers of sarcomeres along the fibres rather than to changes in sarcomere length.

The length of a sarcomere is determined by the length of its constituent myofilaments and the extent to which they overlap. However, the lengths of the actin and myosin filaments were unaltered by the dietary restriction (Table 3 ). Dimensional changes in the sarcomeres or in their ultrastructural components do not, therefore, contribute to the reduction in fibre length observed during the dietary restriction employed. 


\section{DISCUSSION}

The results have provided the first direct evidence that the length of muscle fibres is affected by dietary restriction and subsequent refeeding. The alterations in fibre length were due entirely to changes in the number of sarcomeres in series along the fibres, a pattern observed by previous workers in several other circumstances.

The length of the myofilaments does not change during life. Once the sarcomeres have achieved their optimal extent of filament overlap soon after birth, their length remains unaltered, and longitudinal growth is brought about by the addition of new sarcomeres to the fibres (Goldspink, 1968). The reverse situation is found in old age, when there is a loss of sarcomeres and a consequent reduction in the length of muscle fibres (Hooper, 1981). Selection for altered body-weight in mice also affected sarcomere number, and thereby fibre length, but left the length of the sarcomeres and the myofilaments unchanged (Hooper, $1976 b$; Hooper \& Hurley, 1983). Again, immobilization in a plaster cast also produced a decrease in fibre length as a result of sarcomere loss (Williams \& Goldspink, 1973). However, a normal number of sarcomeres and a normal fibre length were restored when the cast was removed. This sequence of events closely parallels those found in the present investigation.

The number of sarcomeres along a fibre appears to be regulated by the tension, either active or passive, acting on it. During growth, the increased tension generated by the elongating bones stimulates the formaton of new sarcomeres (Goldspink, 1968). Sarcomere number declines when the tension acting on the fibres is reduced by immobilization in a plaster cast, but the formation of new sarcomeres soon restores a normal complement when removal of the cast permits the re-establishment of normal tension (Williams \& Goldspink, 1973). In old age, bone length is unaltered (Hooper, 1983), but muscle protein turnover is diminished (Millward, 1978), and the reduction seen in fibre length probably reflects an inability of the fibres to respond to the tension acting on them. The ability to respond to such tension must be critical and the reduced capacity for protein synthesis which must accompany nutritional deprivation would appear to be the obvious cause of the decreased fibre length seen in the present study.

Like many previous studies, the investigation was carried out in mice of an age at which bone growth is incomplete. The length of the long bones of the mice whose diet was restricted is less than that of their control litter-mates (Hooper \& Graham, 1982) and the tension acting on the fibres, the main stimulus to longitudinal growth, must, therefore, be reduced. Consequently, the decrease in fibre length was probably due to the reduced formation of new sarcomeres rather than the loss of established ones. A further study is at present in progress in adult mice to determine whether dietary restriction also results in the loss of established sarcomeres.

Although the mechanisms involved remain to be elucidated, the results reported herein clearly show that the length of muscle fibres is influenced by dietary factors. Longitudinal indices must, therefore, be included in any consideration of the effects of nutritional deprivation on muscle mass.

\section{REFERENCES}

Birzgalis, A. R., Bedi, K. S., Mahon, M. \& Smart, J. L. (1980). Journal of Anatomy 130, 651-652.

Falconer, D. S. (1973). Genetical Research 22, 291-321.

Goldspink, G. (1965). American Journal of Physiology 209, 100-104.

Goldspink, G. (1968). Journal of Cell Science 3, 539-548.

Heffron, J. J. A. \& Hegarty, P. V. J. (1974). Comparative Biochemistry and Physiology 49A, 43-56.

Hegarty, P. V. J. \& Kim, K. O. (1981). Pediatric Research 15, 128-132.

Hegarty, P. V. J. \& Naude, R. T. (1970). Laboratory Practice 19, 161-164.

Hooper, A. C. B. (1976a). Laboratory Practice 25, 147-149. 
Hooper, A. C. B. (1976b). Growth 40, 33-39.

Hooper, A. C. B. (1981). Gerontology 27, 121-126.

Hooper, A. C. B. (1983). Gerontology 29, 221-225.

Hooper, A. C. B. \& Graham, A. (1982). Irish Journal of Medical Science 152, 206.

Hooper, A. C. B. \& Hurley, M. P. (1983). Animal Production 36, 223-227.

Joubert, D. M. (1956). Journal of Agricultural Science 47, 59-102.

Laboratory Animal Science Association (1969). Laboratory Animal Handbooks No. 2. Dietary Standards for Laboratory Rats and Mice [M. E. Coates, P. N. O'Donoghue, P. R. Payne and R. J. Ward, editors]. London: Laboratory Animals Ltd.

Layman, D. K., Swan, P. B. \& Hegarty, P. V. J. (1981). British Journal of Nutrition 45, 475-481.

Millward, D. J. (1978). Transactions of the Biochemical Society 6, 494-499.

Rowe, R. W. D. (1968). Journal of Experimental Zoology 167, 353-358.

Williams, J. P. G. \& Hughes, P. C. R. (1978). Acta Anatomica 101, 249-254.

Williams, P. E. \& Goldspink, G. (1973). Journal of Anatomy 116, 45-55. 